This is the post-print version of the final paper published in Applied Energy, 88(11), 3592-3602, 2011. The published article is available from http://www.sciencedirect.com/science/article/pii/s0306261911002753. Changes resulting from the publishing process, such as peer review, editing, corrections, structural formatting, and other quality control mechanisms may not be reflected in this document. Changes may have been made to this work since it was submitted for publication. Copyright @ 2011 Elsevier B.V.

\title{
Vacuum Insulation Panels (VIPs) for building construction industry - A review of the contemporary developments and future directions
}

\section{Alam, H. Singh, M.C. Limbachiya}

Sustainable Technology Research Centre (STRC), Kingston University, Roehampton Vale, Friars Avenue, London SW15 3DW, UK

\begin{abstract}
Demand for energy efficient buildings has increased drastically in recent years and this trend will continue in the future. Insulating building elements will play a key role in meeting this demand by reducing heat losses through the building fabric. Due to their higher thermal resistance, Vacuum Insulation Panels (VIPs) would be a more energy efficient alternative to conventional building insulation materials. Thus, efforts to develop VIPs with characteristics suitable for applications to new and existing buildings are underway. This paper provides a review of important contemporary developments towards producing VIPs for such applications using various materials such as glass fibre, foams, perlite and fibre/powder composites. These materials have been used in different VIP components and their limitations have not been covered in previous review papers published on this topic. Selection criteria, methods to measure important properties of VIPs and analytical and numerical models presented in the past have been detailed. Limitations of currently employed design tools along with potential future materials such as $\mathrm{Nano} /$ microcellular foams and $\mathrm{SiO}_{\mathrm{x}} / \mathrm{SiNx}$ coatings for use in VIPs are also described.
\end{abstract}

Keywords: Vacuum Insulation Panel (VIP); Thermal insulation; Thermal conductivity; Gas pressure; Thermal bridging effect; Useful life time

\section{Contents}

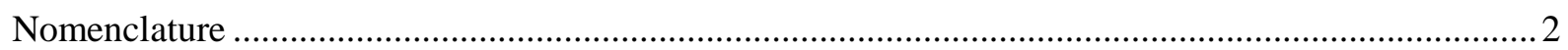

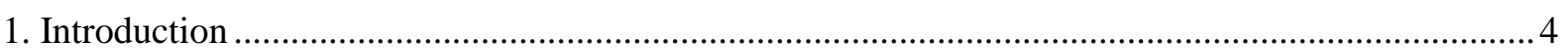

2. Vacuum Insulation Panel (VIP) - Components and materials........................................................ 7

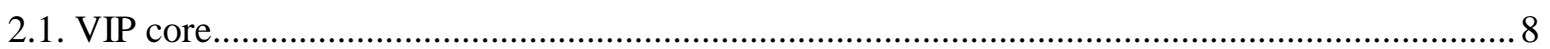

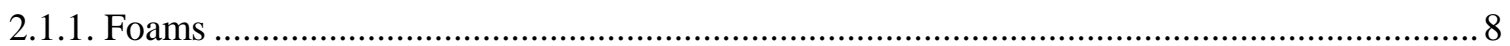

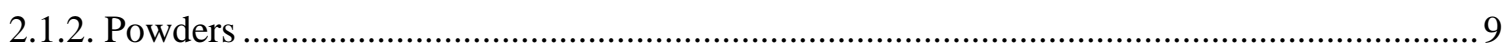

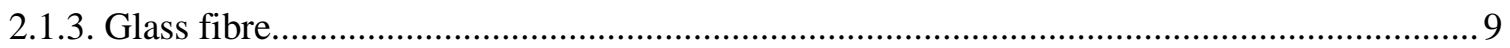

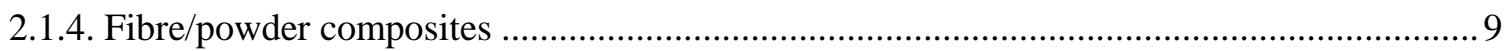

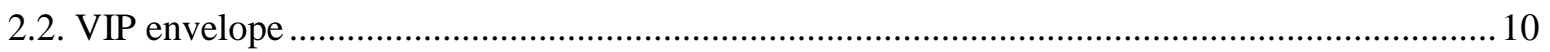

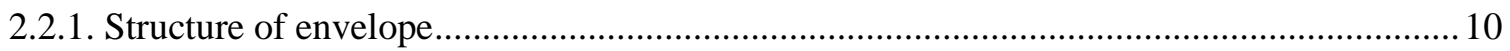

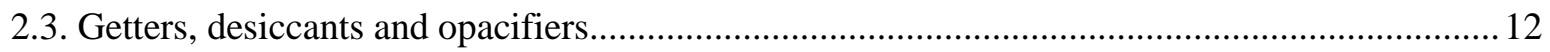

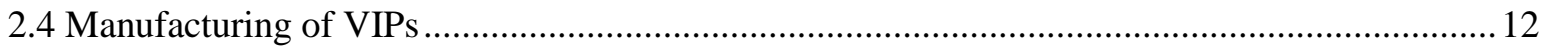

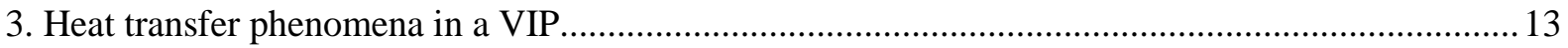


3.1. Solid conduction

3.2. Radiation

3.3. Gaseous thermal conduction

4. Measurement of basic properties of VIPs

5. Aging of VIP .

5.1. Useful life time prediction of VIP

5.2. Thermal bridging effect.

6. Conclusions and future directions

.20

\section{Nomenclature}

$\mathrm{n} \quad$ mean index of refraction

$\mathrm{T}_{\mathrm{r}} \quad$ average temperature within the insulation material $(\mathrm{K})$

$\mathrm{E} \quad$ extinction coefficient of the insulating material $\left(\mathrm{m}^{-1}\right)$

$\mathrm{K}_{\mathrm{n}} \quad$ Knudsen number which is equal to $1 / \Phi$

1 mean free path of the gas molecules $(\mathrm{m})$

$\mathrm{P} \quad$ pressure $(\mathrm{Pa})$

$p_{1 / 2 \text {,gas }} \quad$ Pressue at which the gaseous thermal conductivity equals one half of $\lambda_{\text {free gas }}$ (Pa)

$p_{\text {gas }} \quad$ gas pressure $(\mathrm{Pa})$

$b \quad$ sorption isotherm constant

Xw water content ( $\%$ mass)

$\mathrm{u} \quad$ moisture content (\% mass)

$\mathrm{T} \quad$ temperature $(\mathrm{K})$

$\mathrm{d}_{\mathrm{p}} \quad$ panel thickness $(\mathrm{m})$

$\mathrm{p}_{\mathrm{g}} \quad$ pore gas pressure $(\mathrm{Pa})$

$\mathrm{p}_{\mathrm{g} ; \mathrm{e}} \quad$ atmospheric gas pressure $(\mathrm{Pa})$

$\mathrm{p}_{\mathrm{wv} ; \mathrm{e}} \quad$ partial water vapour pressure outside the VIP (Pa)

$\mathrm{t} \quad$ time (s)

$t_{\text {get }} \quad$ time shift due to a getter (s)

$t_{\text {des }} \quad$ time shift due to a desiccant (s)

$t_{g} \quad$ time constant for gas pressure increase (s)

$t_{w} \quad$ time constant for water content increase (s)

$\mathrm{d}_{\mathrm{p}} \quad$ VIP thickness (m)

a regression parameter $\left(\mathrm{s} \mathrm{m}^{-(1+c)}\right)$

$\mathrm{b} \quad$ regression parameter $\left(\mathrm{m} \mathrm{K} \mathrm{W}^{-1}\right)$

c regression parameter

$\mathrm{E}_{\mathrm{a}} \quad$ activation energy for permeation through the barrier envelope $\left(\mathrm{J} \mathrm{mol}^{-1}\right)$

$\mathrm{R} \quad$ universal gas constant $\left(\mathrm{J} \mathrm{mol}^{-1} \mathrm{~K}^{-1}\right)$

$l_{p} \quad$ perimeter length of VIP (m)

$\mathrm{s}_{\mathrm{p}} \quad$ surface area of VIP $\left(\mathrm{m}^{2}\right)$ 


\section{Greek symbols}

$\lambda_{\text {cop }} \quad$ centre of panel thermal conductivity $\left(\mathrm{W} \mathrm{m}^{-1} \mathrm{~K}^{-1}\right)$

$\lambda \quad$ eigenvalues $\left(\mathrm{m}^{-1}\right)$

$\Psi_{\text {,VIP edge }}$ linear thermal transmittance $\left(\mathrm{W} \mathrm{m}^{-1} \mathrm{~K}^{-1}\right)$

$\lambda_{\mathrm{w}}$ thermal conductivity of liquid water and water vapour at equilibrium $\left(\mathrm{W} \mathrm{m}^{-1} \mathrm{~K}^{-1}\right)$

$\varphi \quad$ ratio of laminate thickness and laminate thickness at edges

$\lambda_{f} \quad$ laminate thermal conductivity $\left(\mathrm{W} \mathrm{m}^{-1} \mathrm{~K}^{-1}\right)$

$\lambda_{f}^{\prime} \quad$ laminate thermal conductivity at edge $\left(\mathrm{W} \mathrm{m}^{-1} \mathrm{~K}^{-1}\right)$

$\lambda_{\mathrm{c}} \quad$ core thermal conductivity $\left(\mathrm{W} \mathrm{m}^{-1} \mathrm{~K}^{-1}\right)$

$\lambda_{S} \quad$ solid thermal conductivity $\left(\mathrm{W} \mathrm{m}^{-1} \mathrm{~K}^{-1}\right)$

$\lambda_{R} \quad$ radiative thermal conductivity $\left(\mathrm{W} \mathrm{m}^{-1} \mathrm{~K}^{-1}\right)$

$\lambda_{G} \quad$ gaseous thermal conductivity $\left(\mathrm{W} \mathrm{m}^{-1} \mathrm{~K}^{-1}\right)$

$\lambda_{K} \quad$ thermal conductivity due to the coupling effect $\left(\mathrm{W} \mathrm{m}^{-1} \mathrm{~K}^{-1}\right)$

$\rho \quad$ density $\left(\mathrm{kg} \mathrm{m}^{-3}\right)$

nevac thermal conductivity (in evacuated conditions) $\left(\mathrm{W} \mathrm{m}^{-1} \mathrm{~K}^{-1}\right)$

$\lambda_{\text {free gas }}$ thermal conductivity of the free and still gas $\left(\mathrm{W} \mathrm{m}^{-1} \mathrm{~K}^{-1}\right)$

$\Phi \quad$ pore width of the porous insulation material (m)

$\lambda_{0} \quad$ thermal conductivity of air at atmospheric pressure $\left(\mathrm{W} \mathrm{m}^{-1} \mathrm{~K}^{-1}\right)$

B coefficient which depends on accommodation coefficient and the adiabatic coefficient of the gas)

$\varphi \quad$ relative humidity $(\%)$

$\varphi_{\mathrm{e}} \quad$ relative humidity of the air outside the VIP (\%)

$\sigma \quad$ Stefan-Boltzmann constant $\left(5.67 \times 10^{-8} \mathrm{~W} \mathrm{~m}^{-2} \mathrm{~K}^{-4}\right)$

$\alpha \quad$ material specific constant 


\section{Introduction}

In 2007, the UK government set a target to gradually improve the energy efficiency and carbon performance of buildings required via the Building Regulations 2006 Part L. The aim of this was to achieve a zero carbon emission level for new homes by 2016 [1]. This carbon reduction will initially be realised by a $25 \%$ improvement in the energy/carbon performance set in Building Regulations 2006 Part L achieving the Code for Sustainable Homes (CSH) level 3 by 2010; then secondly, in 2013, to a $44 \%$ improvement achieving the CSH level 4; and ultimately in 2016, to zero carbon emissions achieving the CSH level 6 [2]. Further, the UK government intends to set zero carbon targets for new non domestic buildings by 2019 [3]. These standards are expected to assist the UK government significantly in reducing Carbon dioxide $\left(\mathrm{CO}_{2}\right)$ emissions from buildings and achieving the 2050 target to reach net carbon emissions at least $80 \%$ lower than the 1990 baseline as set in the Climate Change Act 2008 [4]. Buildings account for almost half of the UK's total carbon emissions [5] and are directly related to energy consumption. In the first quarter of 2010 domestic and services sectors were responsible for $50 \%$ of total UK energy consumption [6]. A major portion of supplied space heating energy is lost through poorly insulated building fabric. Heat losses can be reduced by lowering the heat transfer coefficient (U-value) of building fabric by applying insulation. It is evident from Fig. 1 that lowering the average U-value from the Building Regulation standard value to that required by level 5 of the $\mathrm{CSH}$ standard will reduce the annual space heating demand and $\mathrm{CO}_{2}$ emissions by $7.8 \mathrm{kWh} \mathrm{m}^{-2}$ and $1.5 \mathrm{~kg} \mathrm{CO}_{2} \mathrm{~m}^{-2}$ respectively. Conventional insulation material such as expanded polystyrene (EPS) requires a more than three time large thickness as compared to Vacuum Insulation Panels (VIPs) to lower the average U-value of building as required by the CSH.

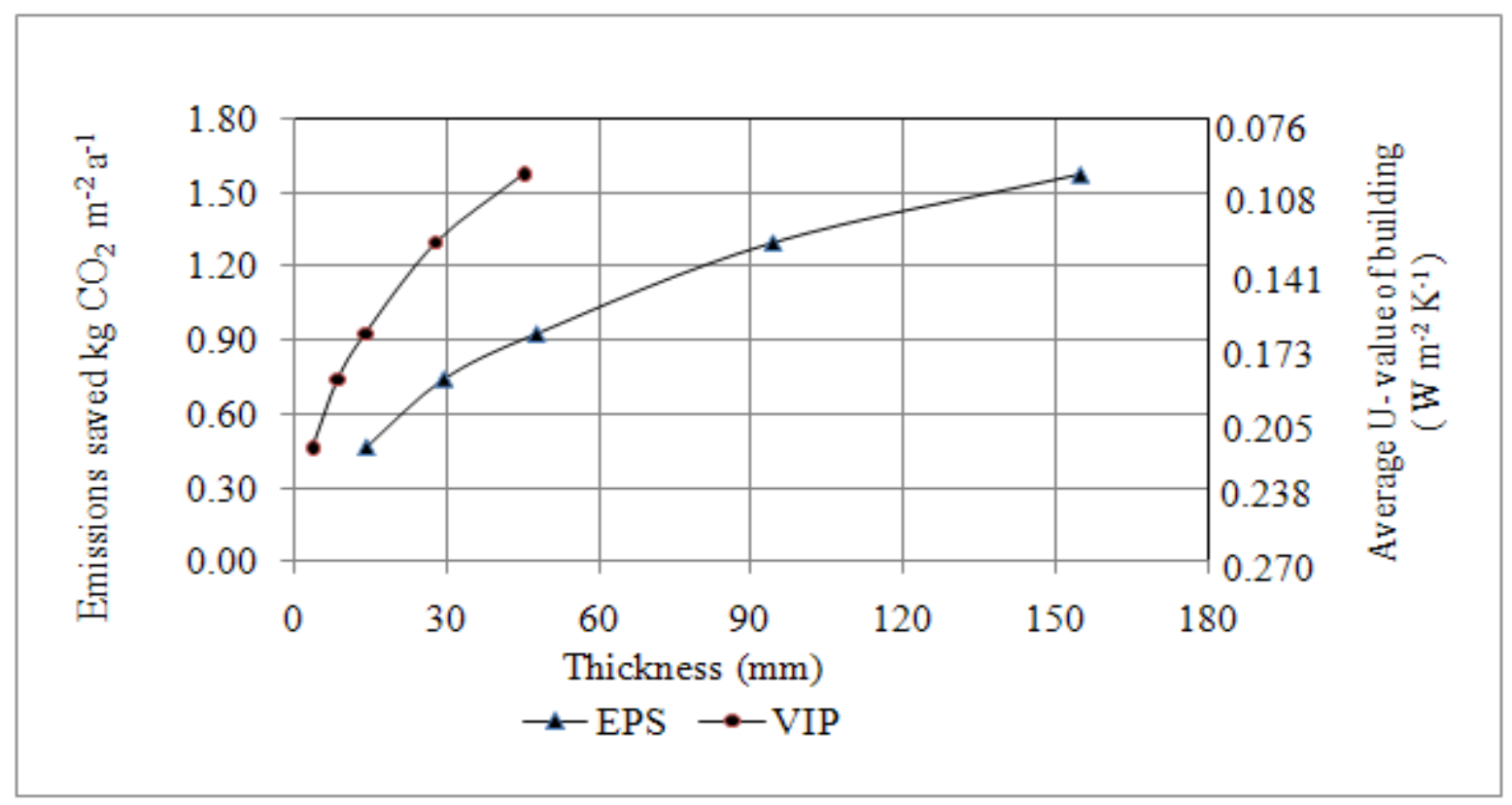

(a) 


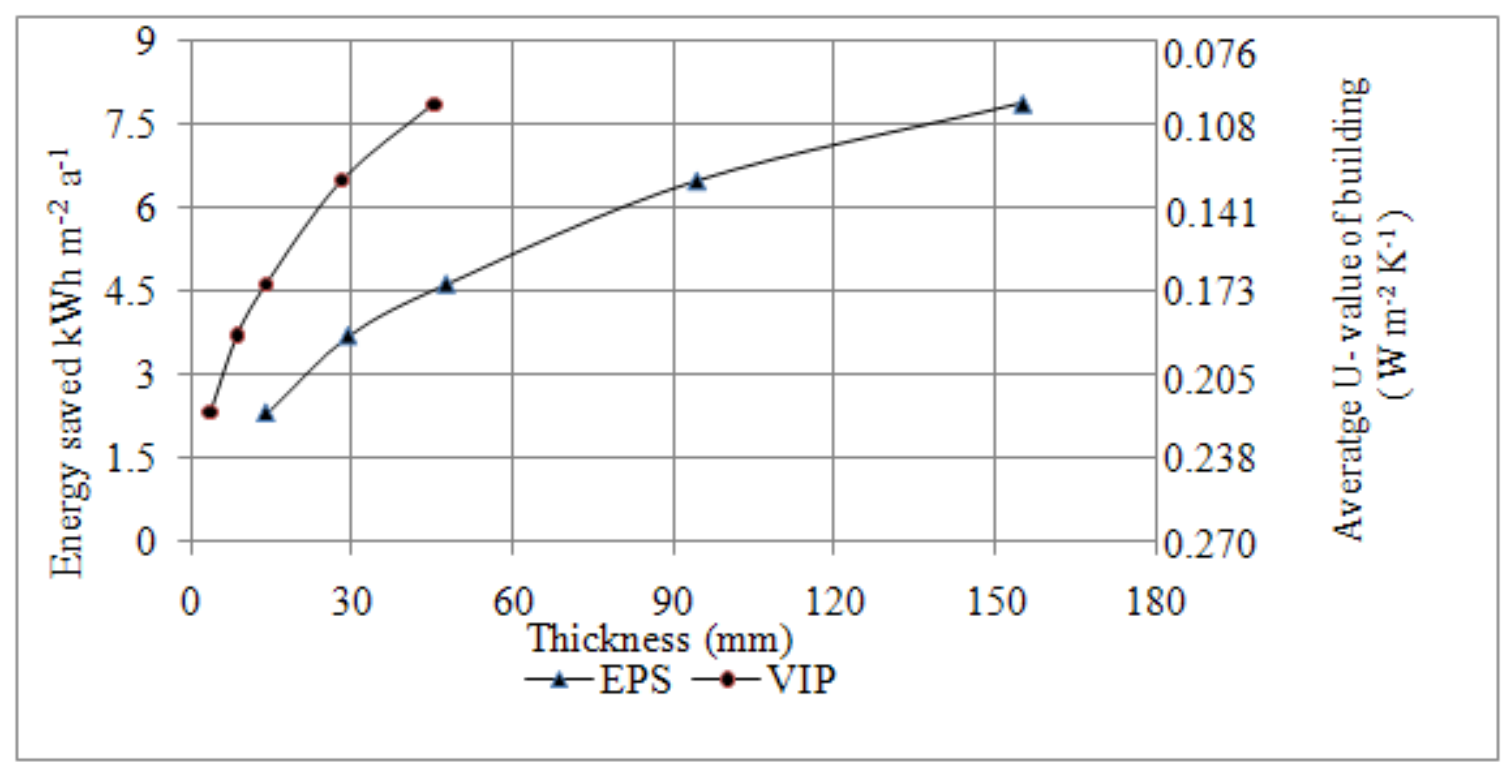

(b)

Fig. 1 (a) Emission saved and required thickness of EPS and VIP (b) Energy saved and required thickness of EPS and VIP

Other insulation materials require a much larger thickness. It is shown in Fig.2 that conventional insulation materials such as rock wool and glass fibre require a large thickness to lower the U-value of a typical masonry cavity wall of a semi-detached UK dwelling (built between 1945 and 1964) from $0.53 \mathrm{~W} \mathrm{~m}^{-2} \mathrm{~K}^{-1}$ to $0.15 \mathrm{~W} \mathrm{~m}^{-2} \mathrm{~K}^{-1}$ as required by the PassivHaus standard [7]. This large thickness of insulation may not be feasible in existing and new buildings due to space and techno-economic constraints. Vacuum Insulation Panels (VIPs) with thermal resistance potentialy 5-8 times higher than convetional insulation [8] offer a solution to the problem. VIPs can be applied to buildings at various locations, for either external or internal surfaces, such as walls, roof, ground floor, window frames, and on hot water cylinders. However, the application of VIPs in buildings has two main barriers; high cost and uncertainity over useful useful life time. Fig.3 shows different scenarios of insulating the unit area of building elements except windows using VIP and EPS and corresponding payback period. In scenario 1 and 2, 10 and $25 \mathrm{~mm}$ thick VIPs are assumed to be applied as insulation material and payback period is between 15-25 years which is extremely high and may not be feasible for buildings. In scenario 3, payback periods of VIP and EPS of $60 \mathrm{~mm}$ are compared and it is shown that VIP payback is more than five times higher as compared to EPS, although better U-value of $0.41 \mathrm{~W} \mathrm{~m}^{-2} \mathrm{~K}^{-1}$ can be achieved with VIPs as compared to $0.49 \mathrm{~W} \mathrm{~m}^{-2} \mathrm{~K}^{-1}$ with EPS. Scenario 4 compares the payback period of insulation required to achieve the U-value of $0.1 \mathrm{~W} \mathrm{~m}^{-2} \mathrm{~K}^{-1}$ which is required to achieve the Code for Sustainable Home level 5. The difference of payback period of EPS and VIP is less than four times which is slightly better than scenario 3. In scenario 5, payback period of both insulations with optimum thickness required for different elements is shown and it is apparent that EPS has shorter payback period than VIP. The main reason of longer payback period of VIP insulation in all scenarios is its high cost and it is required to reduce the cost significantly 
in coming years to make it competitive with other insulation materials. In case of commercial buildings, potential space savings due to low thickness of VIPs can compensate the high cost of VIP.

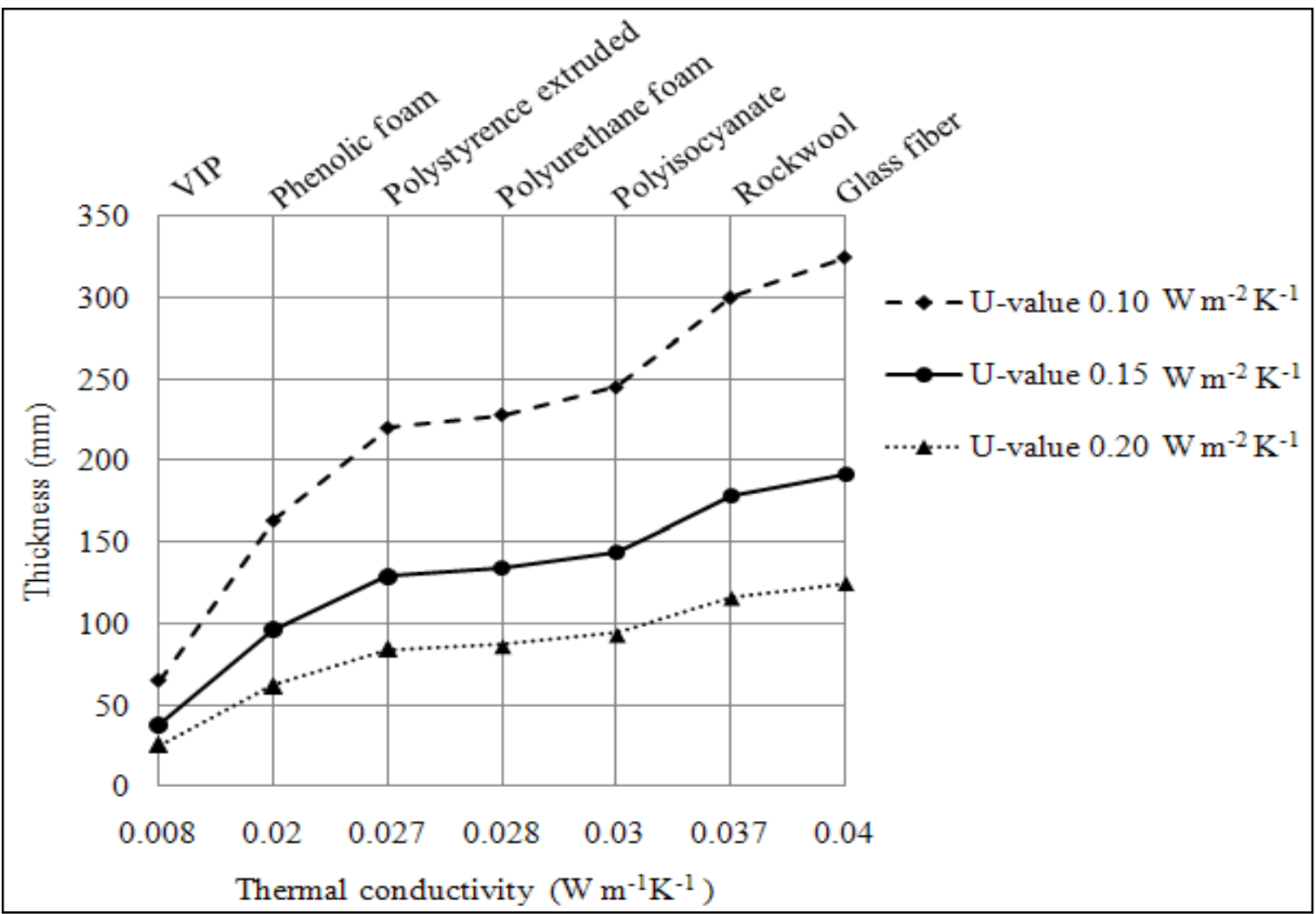

Fig.2. Thicknesses of different insulation materials required to achieve different $\mathrm{U}$-values (W $\mathrm{m}^{-2} \mathrm{~K}^{-1}$ ) for a typical masonry cavity wall of U-Value $0.53 \mathrm{~W} \mathrm{~m}^{-2} \mathrm{~K}^{-1}$ 


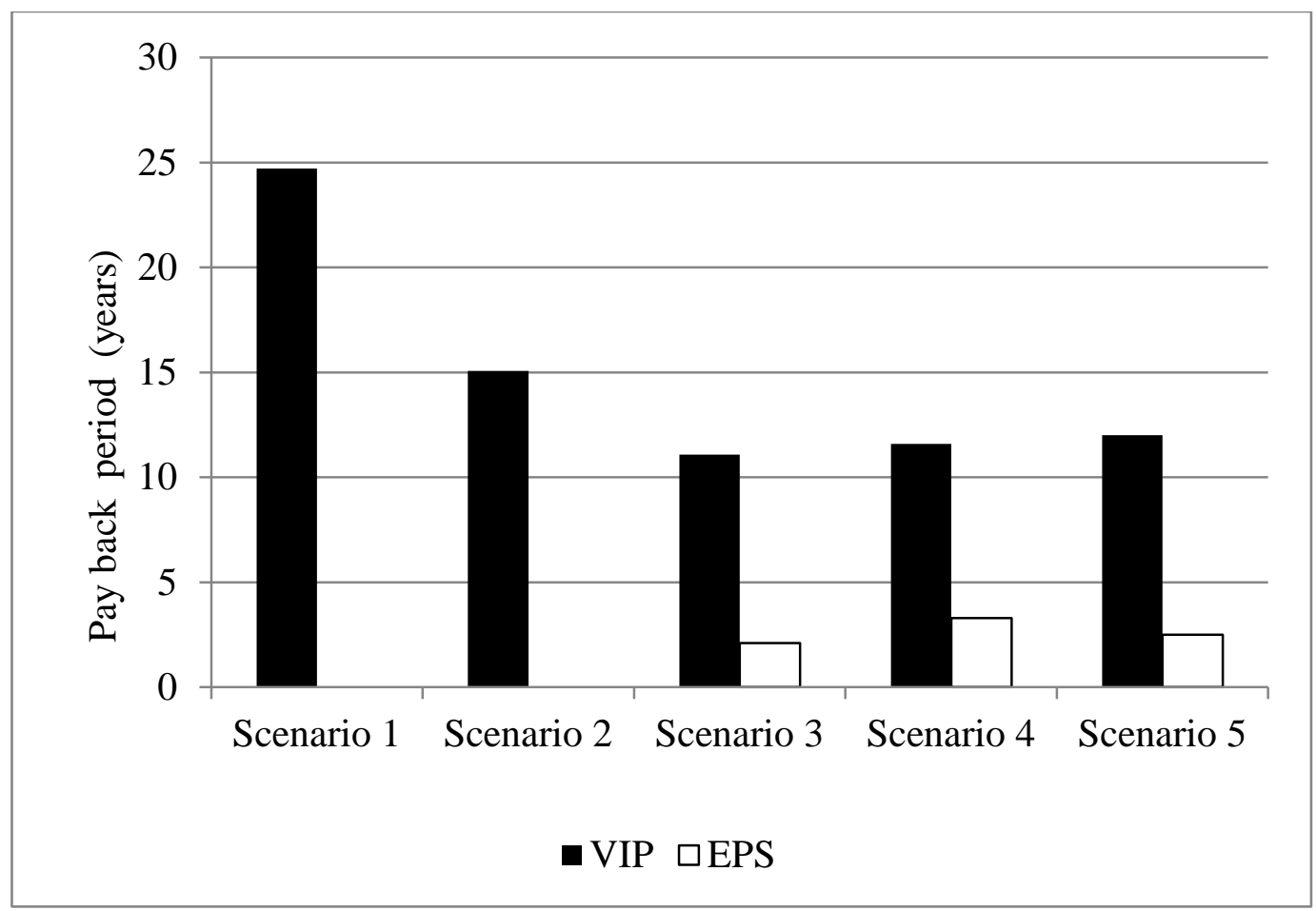

Fig.3. Payback period of VIP and EPS in different scenarios of insulation in buildings

Dewar's flask a vacuum insulation, first used by Sir James Dewar in 1892 consisted of a double wall separated with an evacuated space to store liquid gases [9]. The idea was commercially employed in 1904 by Thermos $\mathrm{GmbH}$ in the production of vacuum flask called Thermos [10,11]. Frick et al. [11] described US patent 236788 as the first precise vacuum insulation panel in which Bovenkerk [12] used an improved welding of glass fibre kernel to walls of panel envelope. Pierre and Daniel [13] used ultrafine silica based compact granular structure for obtaining low thermal conductivity in 1979 to use it as insulating material in buildings and fields involving high and low temperatures. Young and Schreck [14] developed a light weight vacuum thermal insulation panel made up of laminated plastic and aluminium sheet envelope with a plastic edge stripe filled with glass fibre mat in 1984. Nowobilski et al. [15] developed a panel comprised of metal-plastic dual laminate with a glass fibre inner core in 1988 for insulating cryogenic equipment.

\section{Vacuum Insulation Panel (VIP) - Components and materials}

A VIP can be described as an evacuated open porous material placed inside a multilayer envelope as shown in Fig.4. The main components of a VIP are inner core, barrier envelope and getters $\&$ desiccants. The envelope could either consist of thick metal sheets or multilayer barrier of metalized polymeric layers to provide protection against environmental and handling stresses. A suitable getter or a desiccant is inserted inside the VIP core to adsorb gases and water vapours which might penetrate into a VIP through envelope barrier. In the case of conventional non-vacuum insulation materials convection in material pores causes the dominant heat transfer across such materials, whereas in VIP this mode of heat transfer is suppressed by creating a vacuum inside the core material. VIPs can either be classified as (i) sheet based VIPs and (ii) film based VIPs [16]. These are also called static VIPs because the vacuum can only be created at the time of manufacturing and cannot be created again over their useful life time. Sheet based VIPs use metal sheet envelope which exhibit better load bearing capacity and resistant to mechanical damages, but suffer from heavier weight and a 
greater thermal bridging effect $[17,18]$. On the other hand, thinner, $(100-150 \mu \mathrm{m})$, and lighter multilayered metalized polymer film envelopes are easily punctured during handling.

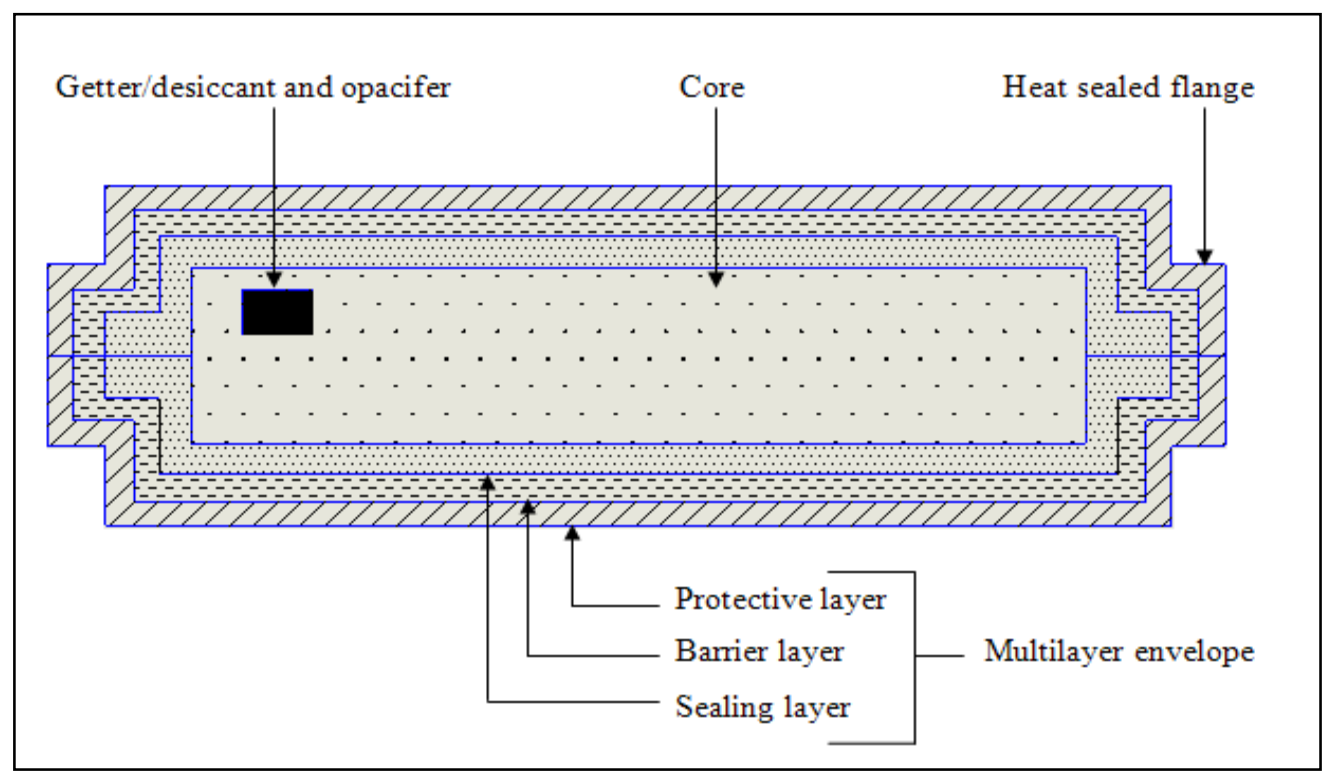

Fig.4. Schematic of a VIP

\subsection{VIP core}

The core, fabricated from porous material of suitable pore size, is the inner part of a VIP as shown in Fig.3. Its function is to maintain the vacuum below a minimum critical level and to physically support the VIP envelope. Gaseous heat transfer is suppressed within the core using small size porous materials such as open porous foams, powders and fibres.

\subsubsection{Foams}

Open cell foams such as polyurethane and polystyrene with pore sizes in the range of 30-250 $\mu \mathrm{m}$ can be used as a core in VIPs. These have low thermal conductivity in evacuated conditions due to their low density $\left(60-100 \mathrm{kgm}^{-3}\right)$ and small pore size of foam materials. However, a low gas pressure, $\leq 0.1 \mathrm{mbar}$, is required to achieve a reasonable thermal resistance in the case of foams, used as VIP core material. Kwon et al. [19] calculated the value for the total thermal conductivity of polyurethane foam of pore size $100 \mu \mathrm{m}$ as 0.0078 $\mathrm{W} \mathrm{m}{ }^{-1} \mathrm{~K}^{-1}$ at 0.01 mbar. However, such a low pressure is not feasible to maintain over the useful life time of the VIP, which is expected to be 50 years or longer for building applications. For foams with a density of $70 \mathrm{~kg} \mathrm{~m}^{-3}$ the radiative and solid conductivity at 300 $\mathrm{K}$ was reported as $0.0027 \mathrm{Wm}^{-1} \mathrm{~K}^{-1}$ and $0.003-0.007 \mathrm{~W} \mathrm{~m}^{-1} \mathrm{~K}^{-1}$ respectively [19], with a combined solid and radiative conductivity in the range of $0.0057-0.0097 \mathrm{~W} \mathrm{~m}^{-1} \mathrm{~K}^{-1}$, a value higher than the normally accepted design thermal conductivity value for a VIP core of 0.004 $\mathrm{W} \mathrm{m}{ }^{-1} \mathrm{~K}^{-1}$. Clearly it would be difficult to achieve this lower thermal conductivity value using foams in VIPs even with zero gaseous conductivity. However, foams are cost effective materials and capable of providing higher thermal resistance compared to other conventional insulation materials such as rock wool and glass fibre for the same insulation thickness as shown in Fig.1. Thermal conductivity of foams can be reduced further by reducing the size of pores. Recently, rubber blended polypropylene and polyethylene nano/microcellular foam (average cell diameter $0.5-2 \mu \mathrm{m}$ ) has been developed by $\mathrm{CO}_{2}$ pressure quench method [20]. 
Nano/microcellular foams with improvised structural arrangement, though currently in the development phase, are potential candidates for VIP core materials in the medium term.

\subsubsection{Powders}

Currently fumed or pyrogenic silica, silica aerogels and expanded perlite individually or in a mixture form are employed in VIP cores. Fumed silica is commonly used due to its ability to yield a low thermal conductivity $0.003-0.006 \mathrm{~W} \mathrm{~m}^{-1} \mathrm{~K}^{-1}$ whilst requiring a pressure in the range of 20-100 mbar [21] owing to a favourable pore size of $300 \mathrm{~nm}$ and a specific surface area in the range of $50-600 \mathrm{~m}^{2} \mathrm{~g}^{-1}$. Its density is approximately $150-200 \mathrm{~kg} \mathrm{~m}^{-3}$. Fumed silica was first developed by Degussa AG (currently Evonik Industries) in Germany in 1942 [22]. Due to its low density, high specific surface area and low thermal conductivity fumed silica is suitable core material for VIPs to achieve the accepted core thermal conductivity design value of $0.004 \mathrm{~W} \mathrm{~m}^{-1} \mathrm{~K}^{-1}$.

Silica aerogels, first developed by Kistler in 1931 using sodium silicate [23], are nano porous materials with pore size of approximately $20 \mathrm{~nm}$ and a density in the range of 3 to $350 \mathrm{~kg} \mathrm{~m}^{-3}$. In general, aerogels are made by two steps (i) wet gel formation by acidic condensation or sol-gel process (ii) drying of wet gel by using supercritical or ambient drying to produce silica aerogel [24]. A low density and a smaller pore size (1-100 nm) render silica aerogel a thermal conductivity of (approximately 0.001-0.003 in evacuated and opacified conditions depending on temperature) making it suitable for VIP applications. However, due to its high cost it has not been widely used in VIPs for building applications.

Expanded perlite, was found to be less effective than silica aerogel and fumed silica requiring a low pressure below 0.1 mbar to achieve the desired design centre of panel thermal conductivity value [25]. Expanded perlite can be used in combination with fumed silica in different mass ratios and such a mixture can be optimized to achieve a low thermal conductivity at a comparatively high pressure for a specified useful life of the VIP. However, it is not expected to achieve typical design centre of panel value at reasonable pressure.

\subsubsection{Glass fibre}

Glass fibre can also be used as the core of a VIP for high temperature applications due to its low density and high thermal stability $\left(>1000^{\circ} \mathrm{C}\right)$. Kwon et al. [19] reported a radiative conductivity of $0.0007 \mathrm{~W} \mathrm{~m}^{-1} \mathrm{~K}^{-1}$ and a solid conductivity of approximately $0.0021 \mathrm{Wm}^{-1} \mathrm{~K}^{-1}$ for glass fibre (density of $250 \mathrm{~kg} \mathrm{~m}^{-3}$ and a fibre diameter of $0.5-0.7 \mu \mathrm{m}$ ) at $300 \mathrm{~K}$. Collectively this results in a thermal conductivity of $0.0028 \mathrm{~W} \mathrm{~m}^{-1} \mathrm{~K}^{-1}$ requiring a suppression of the gaseous conductivity within $0.0012 \mathrm{~W} \mathrm{~m}^{-1} \mathrm{~K}^{-1}$ to achieve a VIP core thermal conductivity of $0.004 \mathrm{~W} \mathrm{~m}^{-1} \mathrm{~K}^{-1}$. A pressure of approximately $0.01 \mathrm{mbar}$ was required to suppress the gaseous thermal conductivity to a negligible level [26]. Kwon et al. [19] also reported a theoretical total thermal conductivity value of $0.0036 \mathrm{~W} \mathrm{~m}^{-1} \mathrm{~K}^{-1}$ for a glass fibre core at 0.1 mbar. Araki et al. [27] investigated the performance of glass fibre based VIPs for insulating hot water cylinders. Glass fibre based VIPs are a good candidate for domestic ovens, furnaces, concentrated solar power plants and fuel cell power plants.

\subsubsection{Fibre/powder composites}

Mukhopadhyaya et al. [28] proposed the use of composites of glass and mineral oxide fibre with pumice and zeolite powder as VIP core material. Thermal conductivity of these materials was found to be comparable to precipitated silica and nanogels for a pressure range of 0.25-100 mbar. A lower embedded energy of such composites compared to that of silica based materials is expected to improve life cycle rating of VIP as they require. Low cost 
alternatives, such as, wood fibre composite with pumice powder[28], are also being considered, though their real time effectiveness in VIPs has not been reported yet.

\subsection{VIP envelope}

The envelope not only protects the VIP from air and water transmission but also provides mechanical strength to withstand atmospheric pressure and handling stresses during transportation and installation. Performance of the envelope depends upon its barrier properties and capability to resist thermal bridging across the edges. Envelope materials are expected to have a water vapour transmission rate (WVTR) of approximately $0.0001 \mathrm{~g} \mathrm{~m}^{-2} \mathrm{~d}^{-1}$ and oxygen transmission rate (OTR) of $0.001 \mathrm{~cm}^{3} \mathrm{~m}^{-2} \mathrm{~d}^{-1}$ to yield a useful life time of approximately 30-50 years for building applications [29]. However, the range of useful life time 30 to 50 years is wide and life time needs to be specified more precisely to build the confidence in manufacturers and users. A combination of polymers and thin metalized films or metal foils is currently employed to produce VIP envelope [10, 29]. Generally, permeance of multilayer film envelope of a VIP depends on temperature, relative humidity and size of panel [30]. Barrier properties of envelope films can be improved by reducing the number and size of defects in the barrier layer [29]. A typical VIP envelope with three metalized films was reported to have a WVTR and an OTR of 0.003-0.005 $\mathrm{g} \mathrm{m}^{-2} \mathrm{~d}^{-1}$ and $0.001-0.002 \mathrm{~cm}^{3} \mathrm{~m}^{-2}$ $\mathrm{d}^{-1}$ respectively at $23^{\circ} \mathrm{C}$ and $50 \% \mathrm{RH}$ [29]. For a two-layered metallised envelope panel estimated useful life time is 16 to 38 years depending upon panel size and climatic conditions [31]. Clearly, a significant improvement in barrier properties is needed to achieve a useful life time of 50 years or longer for a VIP for building applications. Higher barrier properties of aluminium foil envelope compared to a metalized polymeric envelope are evident. However, an aluminium foil envelope suffers from a higher thermal bridging effect. Linear thermal transmittance values of $0.01 \mathrm{~W} \mathrm{~m}^{-1} \mathrm{~K}^{-1}$ for a metalized film envelope and $0.07 \mathrm{Wm}^{-1} \mathrm{~K}^{-1}$ for an aluminium foil envelope were reported [32].

\subsubsection{Structure of envelope}

A typical VIP envelope consists of three material layers; (i) outer protective layer (ii) barrier layer (iii) inner sealing layer, each serving a distinct function. These layers are joined together as shown in Fig.4 and Fig.5 to form an envelope by using a suitable adhesive such as polyurethane.

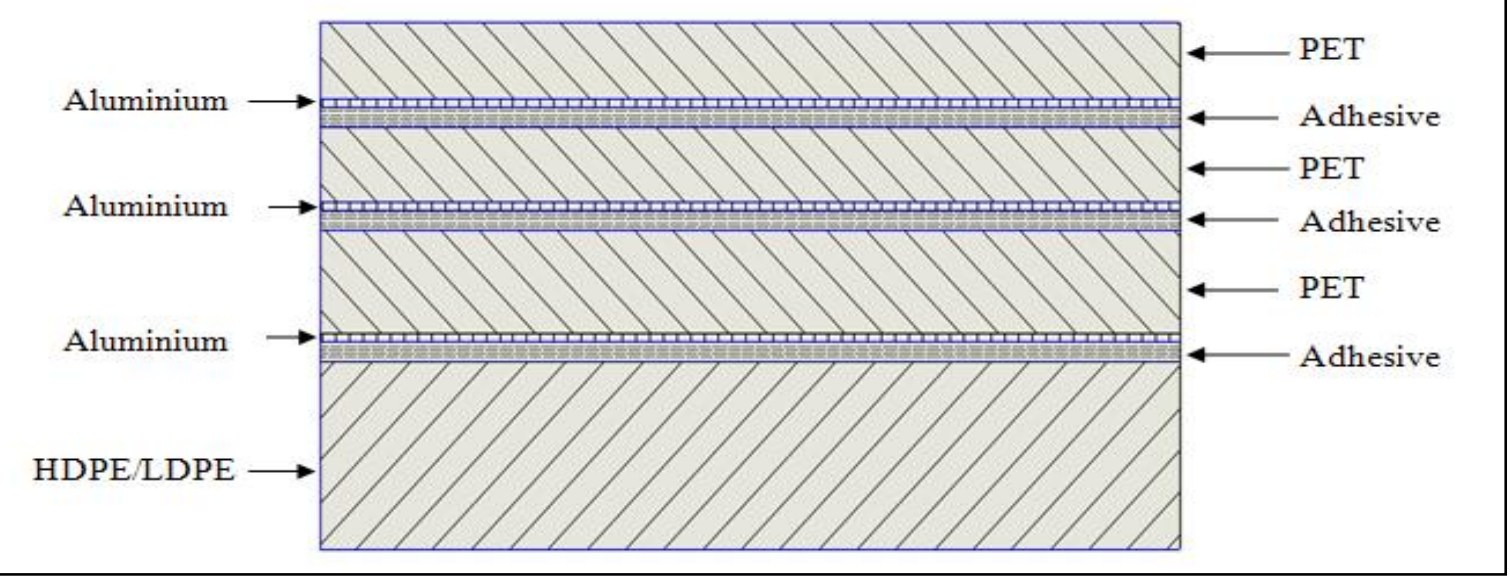

Fig.5. A typical multilayer barrier envelope containing metalized barrier layers 
Kwon et al. [33] proposed a double envelope with an additional porous core material sandwiched between the inner envelope and outer envelope to reduce the gas permeation through the envelope as shown in Fig.6.

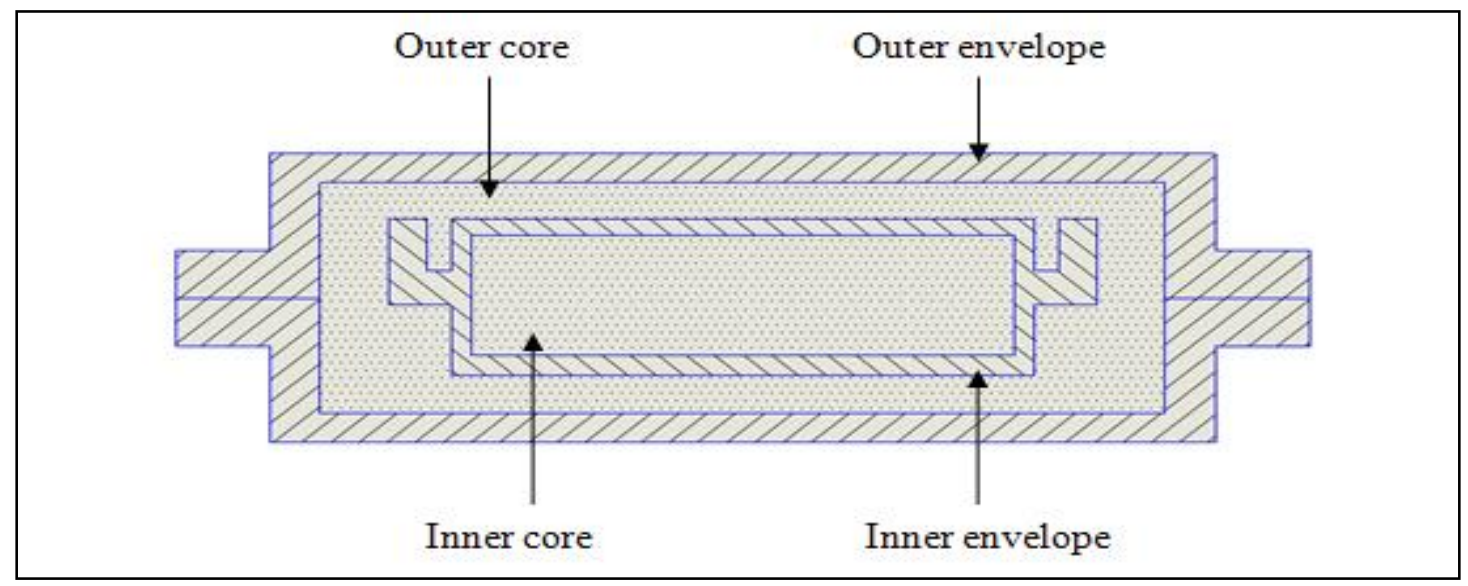

Fig.6. Schematic of a double envelope VIP (redrawn from [33])

\subsubsection{Protective Layer}

It is the outer most layer of the envelope as shown in Fig.4, which protects the VIP from environmental and handling stresses and also acts as a substrate for barrier layer. Currently, polyethylene terephthalate (PET) is used as protective layer due to its low cost and better barrier properties. Use of other materials for envelope is being investigated, for example Araki et al. [27] investigated Nylon 6 (Polyamide) as a protective layer in VIP envelope for high temperature application such as heat pumps and water storage tanks due to its high melting point $\left(225^{\circ} \mathrm{C}\right)$. A drawback of Nylon 6 is its high cost.

\subsubsection{Barrier Layer}

The middle layer (Fig.4) which acts as a barrier against air and water vapour transmission is known as the barrier layer. It is either an aluminium foil or metalized layers of polymers in which aluminium is attached to polymeric substrate. The number of barrier layers in a VIP envelope varies from one to three; though a three layer structure is widely used due to its better barrier properties against air and water vapour transmission. Currently polypropylene (PP) and polyethylene terephthalate (PET) are being used as substrates [34]. Araki et al. [27] investigated the use of metalized layer of ethylene vinyl alcohol copolymer $(\mathrm{EVOH})$ and metallised layer of PET in VIP envelope and found that WVTR and OTR index for this type of envelope were high as compared to the envelope with Al foil. Teniers [35] reported the better barrier properties of metalized layer of EVOH. However, due to the presence of high thermal conductivity metal in such barrier layers the thermal bridging effect on edges of VIP becomes dominant. Thermal bridging effect can be reduced by replacing the metalized barrier layer with silicon oxides $\left(\mathrm{SiO}_{\mathrm{x}}\right)$ and silicon nitride $\left(\mathrm{SiN}_{\mathrm{x}}\right)$ coatings. Barrier properties and mechanical properties of these materials are comparable to the metalized barrier layer [36,37,38,39]. Use of $\mathrm{SiO}_{\mathrm{x}}$ and $\mathrm{SiN}_{\mathrm{x}}$ coated PET in barrier layers for VIPs has not been reported to date. Nevertheless, these materials have great potential for VIP applications and required further investigation. Electrospun Methyltriethoxysilane (MTES) nanofiber fabric [40] is also a potential candidate for the barrier layer due to its high thermal stability and super hydrophobicity. 


\subsubsection{Sealing Layer}

The sealing layer is the inner most layer in a multilayered VIP envelope (Fig.2). This layer seals the core material in the envelope. Heat sealing is a commonly used process to join the laminates. In sealing process the film surfaces are heated between two hot bars under pressure. This creates a bond between two polymer layers due to diffusion. For achieving a better seal, the temperature and time allowed for sealing are very important factors. At a specific initiation temperature, the seal begins to form and its strength increases till a certain maximum value is achieved [41]. Conventionally Low Density Polyethylene (LDPE) and High Density Polyethylene (HDPE) have been used in VIPs as a sealing layer [34]. Malsene et al. [41] experimentally found no significant difference between the seal strength of these materials and concluded that a sealing layer material should be chosen on the basis of its air and water vapour permeability. Araki et al. [27] reported the use of other materials such as polybutylene (PBT) and high retort-cast polypropylene (HR-CPP) as sealing layers for high temperature applications.

\subsection{Getters, desiccants and opacifiers}

Getters and desiccants are placed inside the core to extend the useful life time of a VIP by continuously adsorbing water vapours (desiccants) and gases (getters) which may get into it over its useful life time through either permeation from the outside environment or via out gassing of core and envelope materials or both. In the case of silica core VIPs, core itself acts as a desiccant but for other core materials a small amount of silica gel desiccant is required. Araki et al. [27] used synthetic zeolites getters to adsorb gases for a glass fibre core. Opacifiers are used to reduce the radiative conductivity of the core material by making it opaque to infrared radiation. Silicon carbide $(\mathrm{SiC})$ is the most commonly used opacifier in fumed silica core. Other opacifiers such as carbon black, titanium dioxide $\left(\mathrm{TiO}_{2}\right)$ and iron oxide $\left(\mathrm{Fe}_{3} \mathrm{O}_{4}\right)$ are also being used.

\subsection{Manufacturing of VIPs}

Main steps involved in the manufacturing of a VIP are shown in Fig.7. Heat sealing of the envelope could either be a three sided seal or a four sided seal. Three sided seal has the advantage of reduced gas permeation through the seal flanges compared to four-sided seal [33].

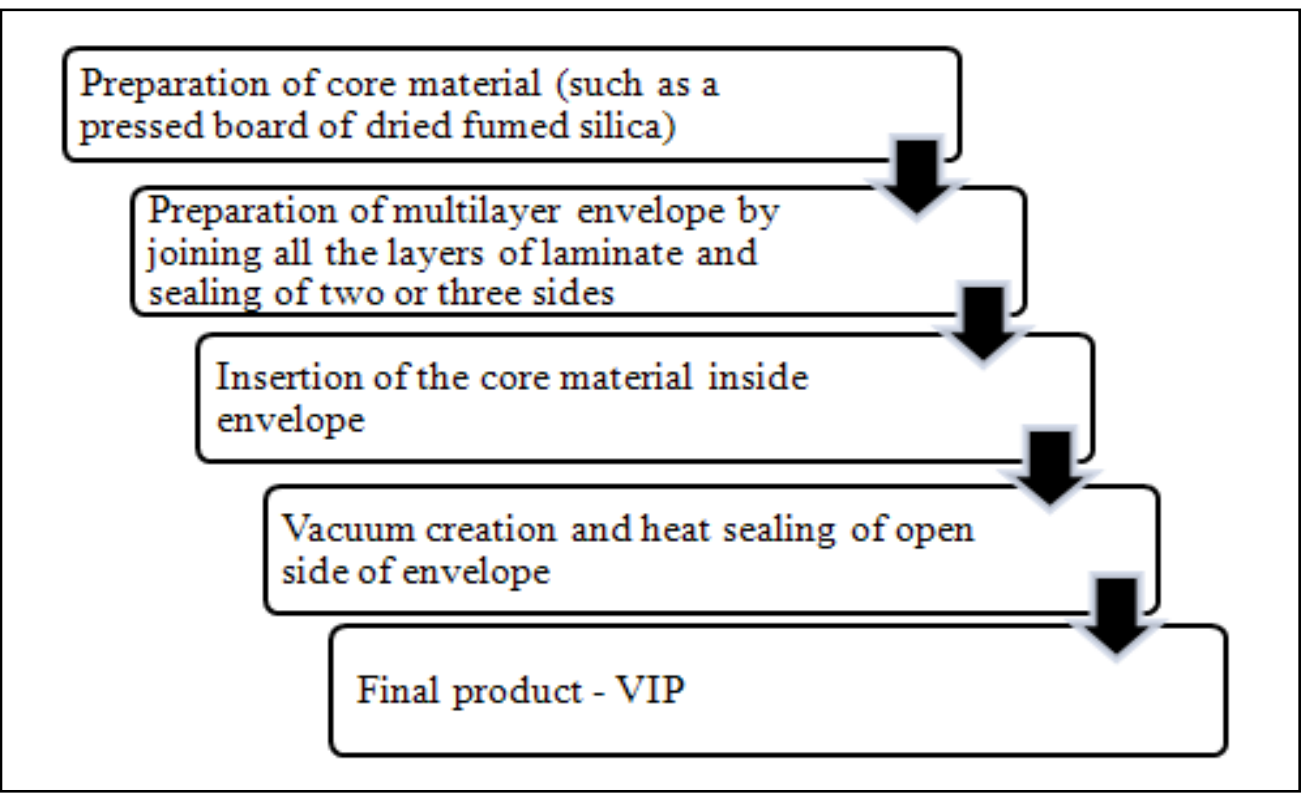

Fig.7. Steps in manufacturing of VIP 


\section{Heat transfer phenomena in a VIP}

With the VIP maintained at a pressure lower than a certain value, sufficient to suppress the convective heat transfer, the remaining modes of heat transfer include solid conduction, radiation and gaseous conduction. Total thermal conductivity of a VIP core can be expressed as [42]

$$
\lambda_{c}=\lambda_{S}+\lambda_{R}+\lambda_{G}+\lambda_{k}
$$

The thermal conductivity $\left(\lambda_{c}\right)$ of VIP core can be reduced by suppressing the thermal conductivity terms shown in the right hand side of equation (1) to minimum and is expected to be in the range of $0.004 \mathrm{~W} \mathrm{~m}^{-1} \mathrm{~K}^{-1}[10,42]$. In equation (1) $\lambda_{k}$ represents coupling effect which becomes evident at higher pressures for powders and fibre materials due to interaction between them in the VIP core.

\subsection{Solid conduction}

Solid conduction occurs through the skeleton of core material whereby the heat is transferred through the physical contact of the constituent particles of the core material. Its magnitude depends upon material structure, density and external pressure on the core. The following correlation was proposed for the variation of solid conductivity with density of the core material [42].

$\lambda_{S}=\rho^{\alpha}$

where the index $\alpha$ has a value of unity for foams and ranges over 1.5 to 2 for nano materials. It is clear from equation (2) that the materials with a low density will yield a smaller solid conductivity.

\subsection{Radiation}

Radiative heat transfer in the form of electromagnetic waves requires no medium and is a significant mode of transferring heat in vacuum conditions. It can be calculated by using equation (3) [42].

$\lambda_{R}=16 \mathrm{n}^{2} \sigma \mathrm{T}_{\mathrm{r}}^{3} / 3 \mathrm{E}\left(\mathrm{T}_{\mathrm{r}}\right)$

Radiative heat transfer can be reduced by adding opacifier to the core material. Caps and Fricke [25] reported that at room temperature thermal conductivity of pure silica is higher by $0.002-0.003 \mathrm{Wm}^{-1} \mathrm{~K}^{-1}$ than that of silicon carbide opacified precipitated silica.

\subsection{Gaseous thermal conduction}

Heat transfer occurs through convection and conduction processes in gases. Its intensity depends on the ratio of mean free path of gas molecules and the pore size of the material i.e., Knudsen Number. Kaganer [43] proposed the following correlation equation (4) to estimate the gas conductivity, $\lambda_{\mathrm{G}}$, as a function of Knudsen Number.

$\lambda_{\mathrm{G}}=\lambda_{0} /\left(1+2 \beta \mathrm{K}_{\mathrm{n}}\right)$

Kwon et al. [19] employed the following correlation, equation (5), to estimate the gaseous thermal conductivity of air at $25{ }^{\circ} \mathrm{C}$ using $\beta=0.0016 / \mathrm{P}$.

$$
\lambda_{\mathrm{G}}=\lambda_{0} /(1+0.0032 / \mathrm{P} \Phi)
$$


By using equation (5) the calculated values of gaseous thermal conductivity of air for different pore sizes are shown as a function of pressure in Fig.6. It can be seen that materials with pore size in the nanometeric range have negligible gaseous thermal conductivity even at atmospheric pressure. It is clear from Fig. 8 that with increasing pore size comparatively lower pressure is required to suppress gaseous thermal conductivity.

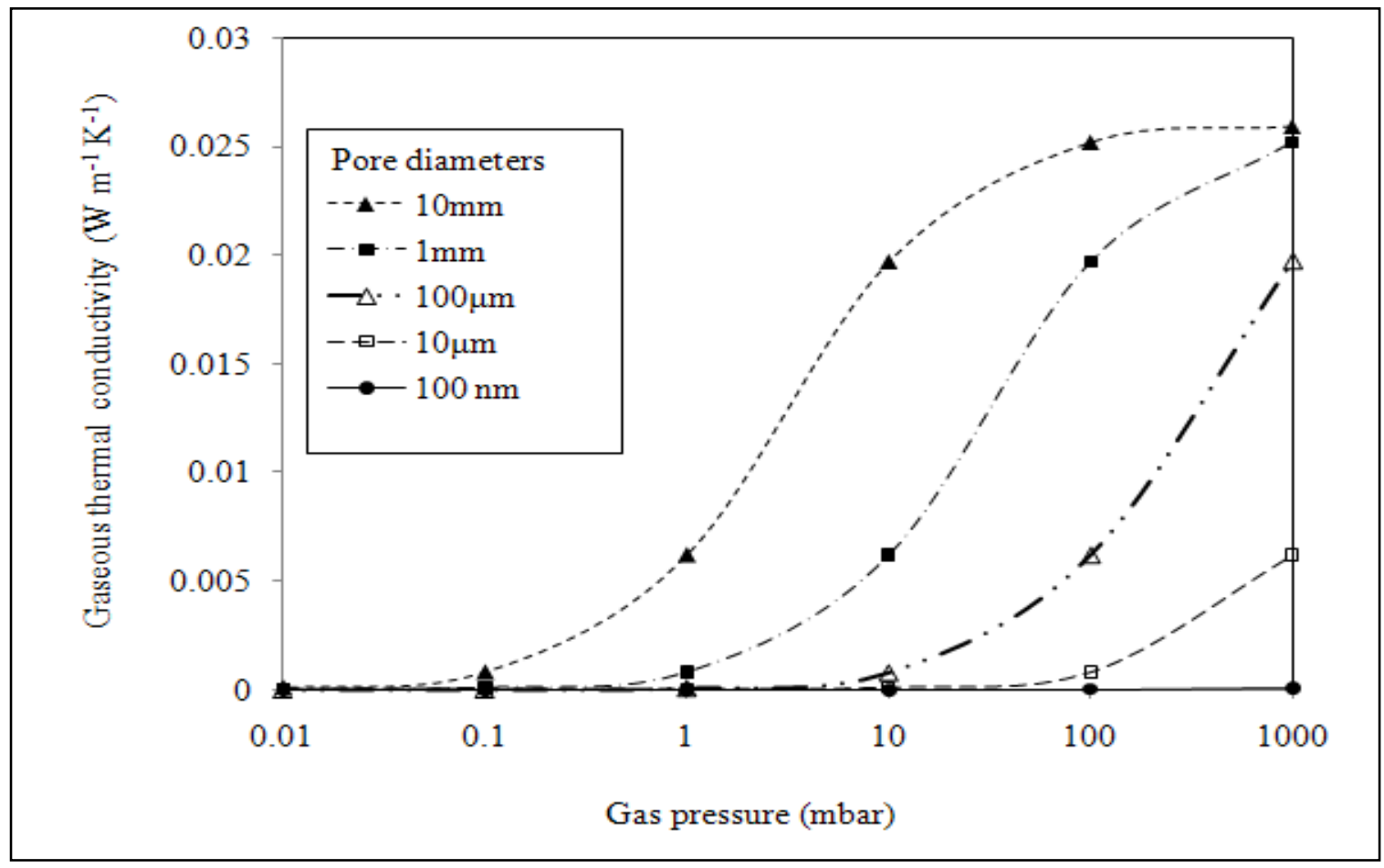

Fig.8. Dependence of gaseous thermal conductivity on pore diameter as a function of gas pressure

\section{Measurement of basic properties of VIPs}

Gas pressure rise inside a VIP core is an important criterion to predict its service life. Pressure increase can be due to addition of gases from one or more of these sources (i) residual gases present inside VIP after manufacturing (ii) out gassing of materials present in envelope and core (iii) permeation through barrier envelope and seal flange [33,44]. Pressure measurement in a VIP is a challenging process as the core is sealed inside an outer envelope. Table 1 details different techniques employed to measure pressure inside a VIP, Water vapour transmission and thermal conductivity.

Table 1: Measurement of basic properties

\begin{tabular}{lllll}
\hline Property & Method & Principle & Advantages & Disadvantages
\end{tabular}




\begin{tabular}{|c|c|c|c|c|}
\hline Pressure & $\begin{array}{l}\text { Spin router } \\
\text { gauge [45] }\end{array}$ & $\begin{array}{l}\text { Stainless steel tube } \\
\text { is attached to the } \\
\text { VIP with a steel } \\
\text { ball suspended in } \\
\text { magnetic field and } \\
\text { made to spin at a } \\
\text { specific speed }\end{array}$ & $\begin{array}{l}\text { Accurate and } \\
\text { less time is } \\
\text { required for } \\
\text { establishing a } \\
\text { trend in increase } \\
\text { in pressure }\end{array}$ & $\begin{array}{l}\text { Risk of leakage on } \\
\text { attaching the tube, } \\
\text { longer observation } \\
\text { time required to } \\
\text { measure the exact } \\
\text { results, dependent on } \\
\text { gas type and not } \\
\text { feasible to use for } \\
\text { large number of VIPs }\end{array}$ \\
\hline & $\begin{array}{l}\text { Foil lift off } \\
{[32,45]}\end{array}$ & $\begin{array}{l}\text { Based on the } \\
\text { principle of } \\
\text { pressure } \\
\text { equilibrium } \\
\text { between inside and } \\
\text { outside the panel }\end{array}$ & $\begin{array}{l}\text { Fast, no special } \\
\text { preparation of } \\
\text { panel required }\end{array}$ & $\begin{array}{l}\text { Not feasible to use } \\
\text { for large number of } \\
\text { VIPs, limited } \\
\text { pressure } \\
\text { measurement range }\end{array}$ \\
\hline & $\begin{array}{l}\text { Radio } \\
\text { frequency } \\
\text { identification } \\
\text { technique } \\
\text { (RFID) } \\
{[45,46]}\end{array}$ & $\begin{array}{l}\text { RFID tag is placed } \\
\text { inside each panel } \\
\text { and data is } \\
\text { retrieved by a } \\
\text { remotely located } \\
\text { data acquisition } \\
\text { system by } \\
\text { identifying radio } \\
\text { waves emitted by } \\
\text { RFID tag }\end{array}$ & $\begin{array}{l}\text { Fast, pressure } \\
\text { measurement } \\
\text { after } \\
\text { installation, } \\
\text { suitable for } \\
\text { measuring } \\
\text { pressure of large } \\
\text { number of VIPs }\end{array}$ & $\begin{array}{l}\text { Not suitable for thick } \\
\text { aluminium foil } \\
\text { envelope }\end{array}$ \\
\hline & $\begin{array}{l}\text { Thermal } \\
\text { measurement }\end{array}$ & $\begin{array}{l}\text { Measurement of } \\
\text { thermal } \\
\text { conductivity of } \\
\text { thin fibre sensor } \\
\text { fleece located } \\
\text { between VIP } \\
\text { envelope and a } \\
\text { metal plate }\end{array}$ & & $\begin{array}{l}\text { Slow and requires } \\
\text { the storage of sample } \\
\text { in Helium gas for } \\
\text { fast measurement, } \\
\text { requires multiple } \\
\text { tests to obtain } \\
\text { accurate results }\end{array}$ \\
\hline WVTR & $\begin{array}{l}\text { Gravimetric } \\
\text { method [47] }\end{array}$ & $\begin{array}{l}\text { Difference in } \\
\text { weight caused by } \\
\text { the water vapour } \\
\text { passing through a } \\
\text { testing material }\end{array}$ & Less expensive & $\begin{array}{l}\text { Slow, Less accurate, } \\
\text { Not suitable for high } \\
\text { barrier materials }\end{array}$ \\
\hline & $\begin{array}{l}\text { Electrolytic } \\
\text { detection } \\
\text { sensor method } \\
{[29]}\end{array}$ & $\begin{array}{l}\text { Electrolyte current } \\
\text { is used to measure } \\
\text { WVTR generated } \\
\text { due to the } \\
\text { moisture carried } \\
\text { by gas flowing } \\
\text { underneath the }\end{array}$ & & \\
\hline
\end{tabular}




\begin{tabular}{|c|c|c|c|c|}
\hline & & sample foil. & & \\
\hline & $\begin{array}{l}\text { Infrared } \\
\text { detection } \\
\text { sensor method }\end{array}$ & $\begin{array}{l}\text { Difference in } \\
\text { relative humidity } \\
\text { across the } \\
\text { specimen film is } \\
\text { measured by an } \\
\text { infra red sensor }\end{array}$ & & \\
\hline \multirow[t]{2}{*}{$\begin{array}{l}\text { Thermal } \\
\text { conductivity }\end{array}$} & $\begin{array}{l}\text { Guarded Hot } \\
\text { Box [48] }\end{array}$ & $\begin{array}{l}\text { The test sample is } \\
\text { placed between the } \\
\text { hot and cold } \\
\text { chambers in which } \\
\text { temperature is held } \\
\text { constant and then } \\
\text { heat transfer } \\
\text { through the sample } \\
\text { is measured. }\end{array}$ & $\begin{array}{l}\text { Slow, } \\
\text { expensive, } \\
\text { requires } \\
\text { auxiliary guard } \\
\text { section and edge } \\
\text { insulation } \\
\text { around }\end{array}$ & \\
\hline & $\begin{array}{l}\text { Heat flow } \\
\text { meter [49] }\end{array}$ & $\begin{array}{l}\text { Sample is placed } \\
\text { between hot and } \\
\text { cold plates and } \\
\text { heat flux is } \\
\text { measured by } \\
\text { transducer after } \\
\text { achieving steady } \\
\text { state conditions }\end{array}$ & $\begin{array}{l}\text { Fast, } \\
\text { Inexpensive }\end{array}$ & $\begin{array}{l}\text { Requires a } \\
\text { calibration factor }\end{array}$ \\
\hline
\end{tabular}

\section{Aging of VIP}

\subsection{Useful life time prediction of VIP}

Useful life time of a VIP is the time period in which total VIP thermal conductivity (i.e. centre of panel thermal conductivity) exceeds a certain limiting value [50]. The variation in gas and water vapour pressure inside the core material determines the change in thermal conductivity of the VIP core. This rate of change of thermal conductivity is employed to predict the useful life time of a VIP [29]. The moisture transmission through a VIP core can be attributed to the Knudsen diffusion and surface diffusion [51]. Knudsen diffusion is molecule-wall collision due to the larger mean free path of the molecules as compared to the pore size and surface diffusion is the movement of molecules along the pore wall [52].

Simmler and Brunner [32] predicted the useful life time for a VIP with silica core and metalized envelope for constant environmental conditions using equation (6) and suggested the preliminary thermal design values of change in core thermal conductivity for useful life time of 25 years for silica VIP $0.006 \mathrm{~W} \mathrm{~m}^{-1} \mathrm{~K}^{-1}$ for aluminium foil and $0.008 \mathrm{~W} \mathrm{~m}^{-1} \mathrm{~K}^{-1}$ for metalized polymeric envelope due to air and water infiltration for at least $20 \mathrm{~mm}$ thick and $250 \mathrm{~mm}$ wide panel.

$\frac{\partial \lambda_{\mathrm{c}}}{\partial \mathrm{t}}=\frac{\partial \lambda_{\mathrm{c}}}{\partial \mathrm{P}} \frac{\partial \mathrm{P}}{\partial \mathrm{t}}(\mathrm{T}, \varphi)+\frac{\partial \lambda_{\mathrm{c}}}{\partial \mathrm{u}} \frac{\partial \mathrm{u}}{\partial \mathrm{t}}(\mathrm{T}, \varphi)$

Schwab et al. [31] presented a correlation (7) for predicting thermal conductivity as a function of time for a fumed silica kernel VIP. In correlation (7) initial thermal conductivity was limited to only solid and radiative conductivity and thermal conductivity due to increase in 
gas pressure and water content over time was added to calculate the time dependent thermal conductivity.

$\lambda(t)=\lambda$ evac $+\frac{\lambda_{\text {free gas }}}{1+\left(p_{1 / 2, \text { gas }} / p_{\text {gas }}(t)\right)}+b \cdot X w(t)$

At $10^{\circ} \mathrm{C}$ thermal conductivity increased by $0.0005 \mathrm{~W} \mathrm{~m}^{-1} \mathrm{~K}^{-1}$ per mass $\%$ of adsorbed water and a $30 \mathrm{mbar}$ increase in gas pressure led to a rise of $0.001 \mathrm{~W} \mathrm{~m}^{-1} \mathrm{~K}^{-1}$ in thermal conductivity [29]. Tenpierik et al. [50] based on the equation (6) proposed an analytical model equation for estimating changes in thermal conductivity over time and useful life time for a VIP with silica core and aluminium foil envelope. This equation (8) includes the rate of change of thermal conductivity due to gas and water vapours as separate terms.

$$
\begin{gathered}
\Delta \lambda_{c}(t) \approx \frac{\partial \lambda_{c}}{\partial p_{g}} p_{g ; e}\left(1-e^{-\frac{t-t_{g e t}}{t_{g}}}\right)+\frac{\partial \lambda_{c}}{\partial p_{w v}} p_{w v ; e}\left(1-e^{-\frac{t-t_{d e s}}{t_{w}}}\right) \\
+\frac{\partial \lambda_{c}}{\partial u} \frac{d u}{d \varphi} \varphi_{e}\left(1-e^{-\frac{t-t_{d e s}}{t_{w}}}\right)
\end{gathered}
$$

For compressed fumed silica a simplified model, (9), was used to approximate rapid estimation of useful life time by assuming nil extension of VIP life using getter and desiccant [48].

$\mathrm{Tsl} \approx \mathrm{ae} \mathrm{e}^{\mathrm{b}\left(\lambda_{\lim }-\lambda_{0}-\lambda_{\mathrm{w}}\right)} \cdot \mathrm{d}_{\mathrm{p}} \cdot\left(\frac{\mathrm{l}_{\mathrm{p}}}{\mathrm{s}_{\mathrm{p}}}\right) \mathrm{c} \cdot \frac{\mathrm{T}_{0}}{\mathrm{~T}} \mathrm{e}^{\mathrm{E} / \mathrm{R}\left(\frac{1}{\mathrm{~T}}-\frac{1}{\mathrm{~T}_{0}}\right)}$

This approximating model is limited to VIP thickness in the range of $0.01-0.05 \mathrm{~m}$, temperature in the range of 268-318 K, perimeter length to surface area ratio in the range of $2-12 \mathrm{~m}^{-1}$ and a constant relative humidity of $50 \%$. However, for building applications constantly changing environmental conditions require a model that is able to predict VIP useful life time under real life transient conditions. Recently, Beck et al. [51] proposed a dynamic simulation model for a silica VIP core under dynamic hygrothermal conditions and was able to simultaneously calculate the moisture transmission and temperature profile of the VIP core.

\subsection{Thermal bridging effect}

It is customary to express the performance of VIPs in terms of either the centre of panel or effective thermal conductivity with later incorporating the effect of thermal bridges around the edges. These thermal bridges appear at three levels for VIP application; (i) VIP level (ii) building components level (iii) facade level [53].Thermal bridges or linear thermal transmittance at VIP level occurs at edges due to the difference in thermal conductivity of evacuated core and surrounding envelope materials. The linear thermal transmittance depends upon the panel thickness, length of perimeter and surface area. Effective thermal conductivity of a VIP can be calculated by adding linear thermal transmittance to centre of panel thermal conductivity as described in equation (10) [29,54]. 
$\lambda_{\text {eff }}=\lambda_{\text {cop }}+\Psi_{\text {,VIP edge }} \cdot d_{p} \cdot l_{p} / s_{p}$

Wakili et al. [54] employed a two-dimensional numerical simulation tool TRISCO to predict the effective thermal conductivity and reported measurements using a guarded hot box. Values of linear thermal transmittance calculated by Wakili et al. [54] for a square-shaped VIP of size $1 \mathrm{~m}^{2}$ are shown in Fig.9. It can be seen that linear thermal transmittance values are higher for a VIP with an aluminium foil $(8 \mu \mathrm{m})$ envelope as compared to the aluminium coated polymeric foil envelopes. Linear thermal transmittance values for a VIP, $10-40 \mathrm{~mm}$ thick, lie in the range of $0.008-0.010 \mathrm{~W} \mathrm{~m}^{-1} \mathrm{~K}^{-1}$ for envelopes consisting of three $12 \mu \mathrm{m}$ metalized PET layers, while for a $6 \mu \mathrm{m}$ aluminium foil it varied between 0.022 and $0.040 \mathrm{~W}$ $\mathrm{m}^{-1} \mathrm{~K}^{-1}$ [55]. Simmler and Brunner [32] calculated the safe design values for linear thermal transmittance to be $0.007 \mathrm{~W} \mathrm{~m}^{-1} \mathrm{~K}^{-1}$ and $0.01 \mathrm{~W} \mathrm{~m}^{-1} \mathrm{~K}^{-1}$ respectively for an aluminium foil and a metallised envelope. Clearly an aluminium foil envelope is not suitable for use in VIP envelope. Thorsell and Kallebrink [56] proposed the serpentine edge design to minimise the linear thermal transmittance at VIP edges. For the stainless steel envelope with 17 serpentines of $20 \mathrm{~mm}$ depth the linear thermal transmittance was reported as $0.0096 \mathrm{~W} \mathrm{~m}^{-1} \mathrm{~K}^{-1}$ compared to $0.028 \mathrm{~W} \mathrm{~m}^{-1} \mathrm{~K}^{-1}$ for a straight steel edge. These values were calculated by using simulation tool Femlab. However, these linear thermal transmittance values were still larger as compared to the values obtained by the Wakili et al. [54] for the metallised and aluminium foil envelopes. Schwab et al. [57] reported similar results and recommended that a minimum panel size of $1 \mathrm{~m}^{2}$ for aluminium foil VIP.

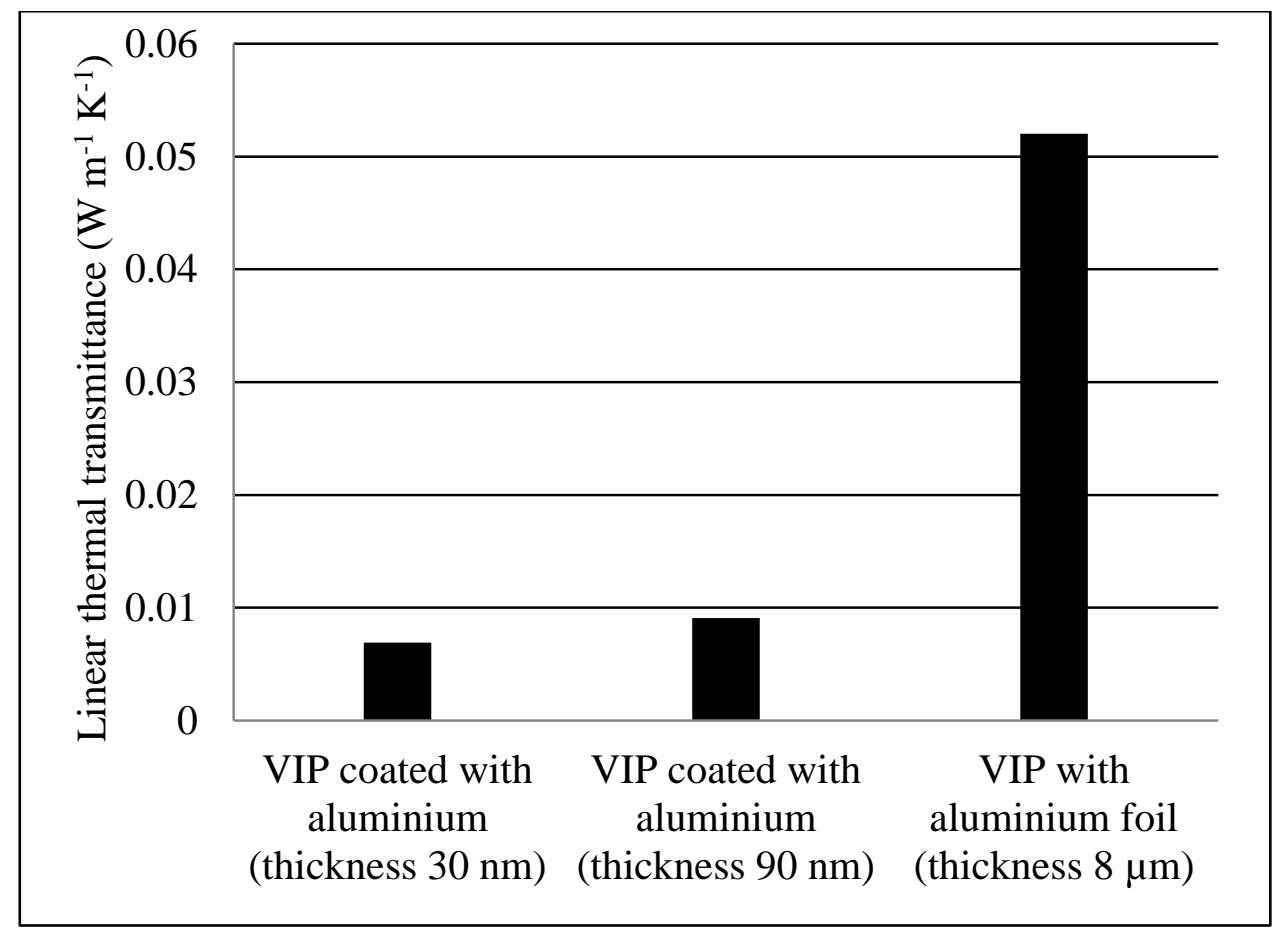

Fig.9. Linear thermal transmittance for different envelope configurations (adapted from [54])

Tenpierik et al. [58] and Tenpierik and Cauberg [59] assuming steady state boundary conditions, no lateral heat transfer between adjacent VIPs and zero thermal conductivity of core presented an analytical model to calculate thermal bridges due to VIP envelope. The 
results of model for non zero core thermal conductivity were validated against the predictions obtained from a commercially available software, TRISCO. Linear thermal transmittance was found to be a complex function of laminate thickness, laminate thermal conductivity, panel thickness and core thermal conductivity. The difference in results of the model and that obtained by TRISCO simulations was much larger for metalized VIP panel with core thermal conductivity $0.002 \mathrm{Wm}^{-1} \mathrm{~K}^{-1}$ and a panel thickness of $20 \mathrm{~mm}$. The results of linear thermal transmittance obtained by simulations for $0.004 \mathrm{~W} \mathrm{~m}^{-1} \mathrm{~K}^{-1}$ core thermal conductivity with aluminium foil, stainless steel foil and metalized film envelope are shown in Fig.10. It is evident from Fig.10 that metalized film presents smaller thermal bridges as compared to aluminium foil and stainless steel envelope but still cannot be neglected due to the low thermal conductivity of VIP.

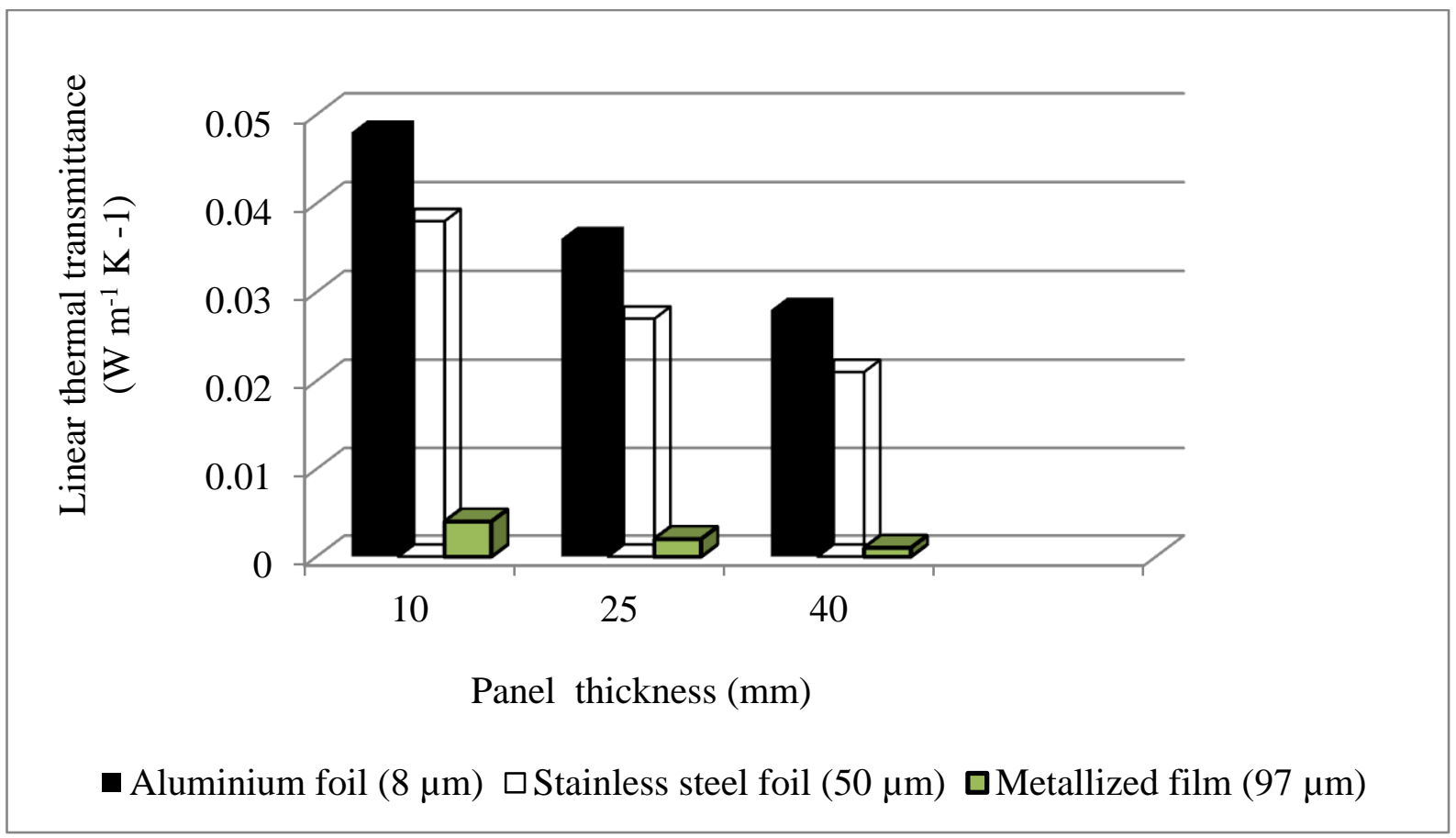

Fig.10. Comparison of linear thermal transmittance of different envelope materials (adapted from [58])

Results of both model and simulations show that materials with higher thermal conductivity in the VIP envelope generated larger thermal bridging effect. Clearly, it is imperative to use low thermal conductivity materials in the VIP envelope to reduce the thermal bridging effect. Thin films of $\mathrm{SiO}_{\mathrm{x}}$ and $\mathrm{SiN}_{\mathrm{x}}$ coated on a polymer substrate can be used to reduce this thermal bridging effect, which is expected to enhance the thermal performance of VIPs.

VIPs often consist of two protecting facings on both sides of the panels linked with a spacer. Schwab et al. [57] estimated the linear thermal transmittance values of expanded polystyrene covered VIPs with aluminium foil and aluminium coated envelopes and found that the presence of expanded polystyrene facing reduced the thermal bridging losses. Nussbaumer et al. [60] also observed the reduced thermal bridging effect when expanded polystyrene was used as a facing in building components. Tenpierik et al. [61] and Quenard and Sallee [53] calculated thermal bridging effect of facing and spacers and found that aluminium and stainless steel facing caused larger values of linear thermal transmittance as compared to polyester facing. Same trend was observed for spacers made up of aluminium as compared to thermoplastic spacer. 


\section{Conclusions and future directions}

VIP is a high performance thermal insulation, with a large potential to reduce the $\mathrm{CO}_{2}$ foot prints of buildings and in conforming to stringent energy standards whilst using minimal existing space. The adoption of VIPs is presently constrained by their limitations namely, susceptibility to damage during installation and development, uncertain useful life time, thermal bridging and high cost. Presently, research is limited to only a few materials which are being used in core and envelope of VIPs and test results available to date are limited to a narrow range of climatic conditions. Thus, new materials, concepts and computer models experimentally validated under realistic climatic conditions are required. The aim of such activities should be to enhance the properties of VIP and reduce their cost making them more attractive to manufacturers, consumers and the construction industry. VIP envelope consisting of PET multiple sheets coated with $\mathrm{SiO}_{\mathrm{x}}$ and/or $\mathrm{SiN}_{\mathrm{x}}$ have a good potential to replace the conventional aluminium and metalized PET films. Silicon coatings are expected to improve the thermal and barrier performance of the VIP envelope. Research needs to be focussed on developing a barrier material which will achieve an OTR of $<10^{-3} \mathrm{~cm}^{3} \mathrm{~m}^{-2} \mathrm{~d}^{-1}$ at $23^{\circ} \mathrm{C}, 50 \%$ $\mathrm{RH}$, and a WVTR of $<10^{-4} \mathrm{~g} \mathrm{~m}^{-2} \mathrm{~d}^{-1}$ at $32^{\circ} \mathrm{C}, 90 \% \mathrm{RH}$ which is expected to yield a useful life time of 50 years or more for VIPs. These coatings are also expectecd to reduce the thermal bridging effect and improve thermal resistance. A comprehensive computer model able to resolve the coupled complex heat and mass (gas and water vapour) exchange phenomena that occur in a VIP system would be a useful tool for researchers to predict VIP performance parameters, thermal conductivity, WVTR and OTR, over a prolonged duration subject to realistic ambient conditions of temperature and humidity. Such a model would assist in identifying the optimum configurations of VIP envelope specifying the type and thicknesses of coatings required for varying thickness of the substrate. One criticism that the fumed silica core material faces is its high market prices (leading to higher a VIP cost). There is a definite scope of cost reduction for VIP core materials by preparing fumed silica-perlite composite, though this might result into some thermal resistance being sacrificed. Optimal proportions for these two materials in the core yielding the lowest possible thermal conductivity need to be ascertained. Open-celled polystyrene modified by employing a suitable filler material is also being seen as a potential core material due to low out gassing properties. The challenge here is to optimise the type, amount and distribution of filler material in the composite to achieve and maintain a suitable vacuum level inside the core to result in design thermal conductivity values with intended useful life of 50 years or more. There is a need of identifying newer adhesive materials, which have a low thermal conductivity and are chemically and physically stable under vacuum conditions and least outgas. Imperfections in sealing seams generally contribute approximately $30 \%$ total gas permeation. Among various components in the surrounding air, water vapour has the highest transmission rate and it permeates about 30,000 times faster than oxygen and nitrogen and is therefore the major contributor to increasing pressure. It is felt that a new class of super hydrophobic sealants and sealing processes is required to overcome the problem of permeation of water vapours through the seal areas. Finally, it is utmost important to employ the knowledge generated in the laboratories to manufacture example VIPs with experimentally validated test results under realistic climatic conditions to earn the confidence of the builders, architects and building managers and owners. 


\section{References}

[1] Department for Communities and Local Government, 2007. Building a Greener Future:policy statement. Available from: http://www.communities. gov.uk/documents/planningandbuilding/pdf/building-greener.pdf

[Accessed 01.07.2010]

[2] Department for Communities and Local Government, 2008. The Code for Sustainable Homes setting the standard in sustainability for new homes. Available from: http://www.com munities.gov.uk/documents/planningandbuilding/pdf/codesustainhomesstandard.pdf [Accessed 01.07.2010]

[3] Department for communities and local Government, 2009. Zero carbon for new non domestic buildings consultation policy options. Available from: http// www. Communities .gov.uk /documents/planningandbuilding/pdf/13991110.pdf.[Accessed 17.04.2010]

[4] Climate Change Act 2008, Crown copyright. Available from: http://www.opsi.gov.uk/acts/acts2008/pdf/ukpga20080027_en.pdf 2008 [Accessed 19.06.2010]

[5] Department of Trade and Industry, 2007. Meeting the Energy Challenge A White paper on Energy Available from: http://www.berr.gov.uk/files/file39387.pdf [Accessed 12.05.2010]

[6] Department of Energy and Climate Change, 2010. Energy Trends - June 2010.

[7] BRE-PassivHaus Primer Available from: http://www.passivhaus.org.uk/filelibrary/BRE-PassivHaus-Primer.pdf [Accessed 20.04.2010].

[8] Brunner S, Simmler H. In situ performance assessment of vacuum insulation panels in a flat roof construction. Vacuum 2008; 82: 700-707.

[9] Fricke J. From Dewars to VIPs - one century of progress in vacuum insulation technology. In: Proceedings of the 7th international vacuum insulation symposium, Duebendorf, Switzerland, 2005.

[10] Fricke J, Schwab H, Heinemann U. Vacuum insulation panel-exciting thermal properties and most challenging applications. International Journal of Thermophysics 2006; 27: 1123-1139.

[11] Fricke J, Heinemann U, Ebert HP. Vacuum insulation panel - From research to market. Vacuum 2008; 8: 680-690.

[12] Bovenkerk HP. 1955. Patent No. 2700633, US.

[13] Pierre GP, Daniel G. 1979. Patent No. 4159359, US.

[14] Young JR, Schreck RM. 1984. Patent No. 4444821,US. 
[15] Nowobiliski JJ, Acharya A, Kather KC. 1988. Patent No. 4726974,US.

[16] Tenpierik M, Cauberg H. Vacuum Insulation Panel: friend or foe? In: Proceeding of 23rd Conference on passive and low energy architecture, Geneva, Switzerland, 2006.

[17] Willems WM, Schild K. The Next Generation of Insulating Materials: Vacuum Insulation. In: Proceedings of the 7th symposium of building physics in the Nordic countries, Reyjhavik, Iceland, 2005.

[18] Willems WM, Schild K, Hellinger G. Numerical investigation on thermal bridge effects in vacuum insulating elements. In: Zimmermann M. Editor, Proceedings of the 7th international vacuum insulation symposium, Duebendorf, Switzerland; 2005.145-152.

[19] Kwon JS, Jang CH, Jung H, Song TH. Effective thermal conductivity of various filling materials for vacuum insulation panels. International Journal of Heat Mass Transfer 2009; 52: 5525-5532.

[20] Nemoto T, Takagi J, Ohshima M. Control of bubble size and location in Nano/Microcellular Poly(propylene)/Rubber Blend Foams, Macromolecular Materials and Engineering 2008; 293: 574-580.

[21] Wang X, Walliman N, Ogden R, Kendrick C. VIP and their applications in buildings: a review. Construction Materials 2007; 160; 145-153.

[22] Evonik Indsutries, Basic properties and characteristics of Aerosil ${ }^{\circledR}$ products, Technical bulletin Fine Particles, Number 11.

[23] Kistler SS, Caldwell AG. Thermal conductivity of silica aerogel. Industrial and Engineering Chemistry 1934; 26: 658-662.

[24] Potter FJ. Nanogel ${ }^{\mathrm{TM}}$, Production, properties, applications. In: Zimmermann M, Bertschinger H. Editors, Proceedings of the international conference and workshop on high performance thermal insulation, Duebendorf, Switzerland, 2001: 33-36.

[25] Caps R, Fricke J. Thermal conductivity of opacified powder filler materials for vacuum insulations. International Journal of Thermophysics 2000; 21: 445-452.

[26] Swimm K, Reichenauer G, Vidi S, Ebert HP. Gas pressure dependence of the heat transport in porous solids with pores smaller than $10 \mu \mathrm{m}$. International Journal of Thermophysics 2009; 30: 1329-1342.

[27] Araki K, Kamoto D, Matsuoka S. Optimization about multilayer laminated film and getter device materials of vacuum insulation panel for using at high temperature, Journal of Materials Processing Technology 2009; 209: 271-282.

[28] Mukhopadhyaya P, Kumaran K, Normadin N, Reen DV. Fibre-powder composite as core material for Vacuum Insulation Panel. In: 9th international vacuum insulation symposium, London, UK, 2009.

[29] Simmler H, Brunner S, Heinemann U, Schwab H, Kumaran K, Mukhopadhyaya P, et al. Vacuum Insulation Panels - Study on VIP-components and Panels for Useful life time Prediction in Building Applications (Subtask A). A Report for the IEA/ECBCS Annex 39 High Performance Thermal Insulation for Buildings and Building Systems 2005, Available from: http://www.ecbcs.org/docs/Annex_39_Report_Subtask-A.pdf [Accessed 26.04.2010].

[30] Schwab H, Heinemann U, Beck A, Ebert HP, Fricke J. Permeation of different gases through foils used as envelopes for vacuum insulation panels. Journal of Thermal Envelope and Building Science 2005; 28: 293-317.

[31] Schwab H, Heinemann U, Beck A, Ebert HP, Fricke J. Prediction of useful life time for vacuum insulation panels with fumed silica kernel and foil cover. Journal of Building Physics 2005; 28: 357-374.

[32] Simmler H, Brunner S. Vacuum insulation panels for building application: Basic properties, aging mechanisms and service life. Energy and Buildings 2005; 37: 11221131. 
[33] Kwon JS, Jang CH, Jung H,Song TH. Vacuum maintenance in vacuum insulation panels exemplified with a staggered beam VIP. Energy and Buildings 2010; 42: 590597.

[34] Brunner S, Gasser P, Simmler H, Wakili KG. Investigation of multilayered aluminiumcoated polymer laminates by focused ion beam (FIB) etching, Surface and Coatings Technology 2006; 200: 5908-5914.

[35] Teniers C. How laminates with EVALTM EVOH film improve the performance of VIPs. In: 9th international vacuum insulation symposium, London, UK, 2009.

[36] Lange J, Wyser Y. Recent innovations in barrier technologies for plastic packaging - a review. Packaging Technology and Science 2003; 16: 149-158.

[37] Amrerg-Schwab S, Hoffmann M, Badera H, Gessler M. Inorganic-organic polymers with barrier properties for water vapour, oxygen and flavours. Journal of Sol-Gel Science and Technology 1998; 13: 141-146.

[38] Howells DG, Henry BM, Laterrier Y, Manson JAE, Madocks J, Assender H.E. Mechanical properties of $\mathrm{SiO}_{\mathrm{x}}$ gas barrier coatings on polyester films. Surface \& Coating Technologies 2008: 208: 3529-3537.

[39] Wolf R, Wandel K, Boeffel C. Moisture barrier films deposited on PET by ICPECVD of SiN. Plasma Process. Polym. 2007; 4: S185-S189.

[40] Lim HS, Baek JH, Park K, Shin HS, Kim J, Cho JH. Multifunctional hybrid fabrics with thermally Stable Super hydrophobicity. Adv. Mater. 2010; 22: 2138-2141.

[41] Malsen JV, Tenpierik MJ, Looman RHJ, Cauberg JJM. Heat seal strength of barrier film used in vacuum insulation panels at room temperature and at $-130^{\circ} \mathrm{C}$. Journal of Plastic Film and Sheeting 2008; 24: 35-52.

[42] J. Fricke. Materials research for the optimization of thermal insulations. High Temperatures-High Pressures 1993; 25: 379-390.

[43] Kaganer MG. Thermal insulation in cryogenic engineering, translated by A. Moscona, Israel programme for scientific translation Ltd. 1969.

[44] Porta PD. Gas problem and gettering in sealed-off vacuum devices. Vacuum 1996; 47: 771-776.

[45] Caps R, Beyrichen H, Kraus D, Weismann S. Quality control of vacuum insulation panels: methods of measuring gas pressure. Vacuum 2008; 82: 691-699.

[46] Caps R, Beyrichen H. Monitoring gas pressure in vacuum insulation panels. In: Zimmermann M, Editor, Proceedings of the 7 th international vacuum insulation symposium, Duebendorf, Switzerland; 2005.57-66.

[47] British Standards Institution. BS EN 12086:1997. Thermal insulating products for building applications-Determination of water vapour transmission properties.1999. BSI London.

[48] British Standards Institution. BS EN 12667:2001. Thermal performance of building materials and products - Determination of thermal resistance by means of guarded hotplate and heat flow meter methods - Products of high and medium thermal resistance. 2001. London BSI.

[49] Frawley E, Kennedy DM. Thermal testing of building insulation materials, Engineers Journal 2007; 61: 552-558.

[50] Tenpierik M, van Der Spoel W, Cauberg H. Simplified analytical model for useful life time prediction of a vacuum insulation panel. In: Proceedings of 8th international vacuum insulation symposium, Würzburg, Germany: 2007.

[51] Beck A, Binder M, Frank O. Dynamic simulation of VIP moisture and heat transport. In: Proceedings of 9th international vacuum insulation symposium, London, UK. 2009

[52] Krishna R, Wesselingh JA. The Maxwell-Stefan approach to mass transfer. Chem.Eng. Science 1997; 52: 861-911. 
[53] Quenard D, Sallee H. From VIP's to building facades: three levels of thermal bridges. In: Zimmermann M, Editor, Proceedings of the 7 th international vacuum insulation symposium, Duebendorf, Switzerland; 2005.113-120.

[54] Wakili KG, Bundi R, Binder B. Effective thermal conductivity of vacuum insulation panels, Building Research \& Information 2004; 32: 293-299.

[55] Binz A, Moosmann A, Steinke G, Schonhardt U, Fregnan F, Simmler H, et al. Vacuum Insulation in the Building Sector. Systems and Applications (Subtask B), Final Report for the IEA/ECBCS Annex 39 HiPTI-project High performance thermal insulation for buildings and building systems 2005. Available from: http://www.ecbcs.org/docs/Annex_39_Report_Subtask-B.pdf [Accessed 20.04.2010].

[56] Thorsell T, Kallebrink I. Edge loss minimization in vacuum insulation panels. In: Proceedings of 7 th symposium on building physics in the Nordic countries, Reykjavik, Iceland, 2005.

[57] Schwab H, Stark C, Wachtel J, Ebert HP, Fricke J. Thermal bridges in vacuuminsulated building facades. Journal of Thermal Envelope and Building Science 2005; 28: 345-355.

[58] Tenpierik M, van Der Spoel W, Cauberg H. Analytical model for predicting thermal bridge effects due to vacuum insulation panel barrier envelope. Bauphysik 2008; 30: $38-45$.

[59] Tenpierik M, Cauberg H. Analytical models for calculating thermal bridge effects caused by thin high barrier envelopes around vacuum insulation panels. Journal of Building Physics 2007; 30: 185-215.

[60] Nussbaumer T, Wakili KG, Tanner Ch. Experimental and numerical investigation of the thermal performance of a protected vacuum-insulation system applied to a concrete wall. Applied Energy 2006; 83: 841-855.

[61] Tenpierik M, van Der Spoel W, Cauberg H. An Analytical model for calculating thermal bridge effects in high performance building enclosure. Journal of Building Physics 2008; 31: 361-387. 